\title{
Evaluation of Atatürk Airport in the Perspective of Aviation Security During the Failed Coup Attempt on July 15, 2016 ${ }^{1}$
}

\section{Temmuz 2016'daki Kalkışması Sırasında Atatürk Havalimanının Havacılık Güvenliği Açısından Değerlendirilmesi}

\author{
Assist. Prof. Dr. Savaş S. Ateş²
}

Başvuru Tarihi: 20.11.2019

Kabul Tarihi: 03.12.2019

\begin{abstract}
Humanity has been exposed to many risks, threats and dangers since it began to exist in the world. These risks, threats and hazards did not disappear as they updated themselves over time. Today's counterpart to this atmosphere of fear, which constantly threatens mankind, is the "risk society".

On July 15th, the coup attempt initiated by a group of officers belonging to the Fetullah Terrorist Organization / Parallel State Structure (FETÖ / PDY) within the Turkish Armed Forces was taken under control in less than 24 hours.

Members of the organization attempted to control the apron area and the restricted and custom area in the terminal and apron at Atatürk Airport. The armed forces intervened in the airport security forces, airport personnel and passengers in the apron.

The aim of the study is to analyze flight safety and airport security in Atatürk Airport during the coup attempt of July 15th. In the first part of the research, the concept of risk is given and in the second part, airport safety is given with literature review. In the last section of the research, the visuals published in the press were analyzed and the case study was analyzed and behaviors of against rules about flight safety and airport safety were listed at Atatürk Airport.
\end{abstract}

Keywords: Airport security, Risk Society, July 15th Failed Coup Attempt, Atatürk Airport Case Study

Öz

\footnotetext{
1 This research supported by SİHAGÜVDER (Sivil Havacılık Güvenlik Memurları Derneği)

2 Eskisehir Technical University Faculty of Aviation and Space Sciences, ssates@eskisehir.edu.tr, ORCID ID: 0000-0003-2462-0039
} 
İnsanoğlu dünyada var olmaya başladiğı günden bugüne birçok risk, tehdit ve tehlikelere maruz kalmıştır. Bu risk, tehdit ve tehlikeler zaman içerisinde kendisini güncellediği için de yok olmamıştır. İnsanoğlunu sürekli tehdit eden bu korku atmosferinin günümüzdeki karşıllğ̆ "risk toplumudur".

15 Temmuz 2016'da TSK içerisindeki Fetullahçı Terör Örgütü/ Paralel Devlet Yapılanması (FETÖ/PDY) mensubu bir grup subay tarafindan Genelkurmay Başkanlı̆̆ı Karargâhi’nda başlatılan darbe girişimi 24 saatten kısa zamanda kontrol altına alınmıştır.

Örgüt üyesi askerler Atatürk Havalimanında tahditli alan ihlali yaparak apron bölgesine ve terminal içerisinde yer alan gümrüklü alanı kontrol almaya çalışmıştır. Apron içerisindeki havaalan güvenlik güçleri, havaalan personeli ve yolculara silahlı müdahalede bulunulmuştur.

Araştırmanın amacı 15 Temmuz 2016 kalkışmasında Atatürk Havalimanı uçuş emniyetini ve havaalanı güvenliğinin analiz edilmesidir. Araștırmanın birinci bölümünde risk kavramı, ikinci bölümünde havaalanı güvenliği literatür taraması ile verilmiştir. Araştırmanın son bölümünde basında yayınlanan görseller analiz edilerek örnek olay analiz edilmişve Atatürk Havalimanında uçuş emniyetini ve havaalanı güvenliği hakkında uyulmayan kurallar listelenmişstir.

Anahtar kelimeler: Havaalanı güvenliği, Risk Toplumu, 15 Temmuz 2016 Kalkışması, Atatürk Havalimanı Örnek Olayı

\section{Introduction}

Humanity has been exposed to many risks, threats and dangers since it began to exist in the world. Threats affecting humanity update themselves over time. The current meaning of this atmosphere of fear is "risk society" (Koçak \& Memiş, 2017).

Air transport is one of the factors that provide time and place benefit to the society in the field of transportation. In 2017, more than half of the world's 1.1 billion tourists were transported using approximately 1400 commercial airlines and 4310 airports (ICAO, 2017). Terrorist attacks on aviation have been carried out in the past due to reasons on the scope, scale of air transport, and the relevance of international media. For this reason, the concept of aviation security has been developed. With the aviation security measures, it is tried to prevent criminal activities to aircraft, airports, and others.

The coup attempt initiated by a group of officers belonging to the Fetullah Terrorist Organization / Parallel State Structure (FETO / PDY) in the Turkish Armed Forces on July $15^{\text {th }}$ was taken under control by government in less than 24 hours (Cumurbaşkanlığı Genel Sekreterliği, 2016). President Recep Tayyip Erdoğan called on the public to go out on the streets Then the Turkish people went to the squares and airports that was one of the breaking points for the failure of the coup attempt (Çelikkan, 2017).

58 airport coup officers tried to control them with 4 tanks, 4 armored vehicles, 4 trucks and 4 military jeeps and killed 6 civilians. (HYSK, 2018) (Cumurbaşkanlığı Genel Sekreterliği, 2016). 
The research was carried out for the evaluation of Atatürk Airport on July $15^{\text {th }}$ in terms of airport security. The concept of civil aviation security is given in a narrow framework by literature review. Beck's risk society theory was explained and the importance of Atatürk Airport in July $15^{\text {th }}$ events was evaluated.

\section{Literature Review}

\section{Civil Aviation Security}

In 2018, 280 million airline passengers were carried by airline (Scherer, 2019). The attacks of September 11, 2001 caused a paradigm shift in aviation security in the international system. After September 11, there has been a significant change in the quantity and quality of security approaches (Sandıkl1, 2011). The September 11 attacks highlighted multidimensional security strategies and strengthened the link between the global system and domestic policy (Ateş, Yılmaz, Sayın, \& Kardeş, 2016). Countries have decided that there must be certain rules, improvements and changes in aviation security. International agreements have been proposed by countries and new agreements have been made to identify, measure and punish the responsible persons or organizations. Tokyo Convention, Montreal Convention, Hijacking Convention, Rome Convention, Bonn Convention 1978, 1988 Montreal Protocol and G-7 and Lyon summits are important international regulations in aviation security. Each country has been directly or indirectly involved in these conventions. As aviation is an international activity, member states generally do not find it appropriate to fly to non-member countries (Sweet, 2008, pp. 38-48). The general structure of the safety and security rules for Annex 14, Annex 17 and Annex 19 airports issued by the International Civil Aviation Organization (ICAO) has been determined.

At the national level, it has asked all organizations operating in the aviation sector to go to security structuring. In Turkey, the Directorate General of Civil Aviation (DGCA) issued by the "Aviation Business Management and Organization of Security Instructions" is the framework for aviation security. According to the regulation, all the companies operating in the airport have established security units under their own conditions. Complies with safety rules at airports, including airline operators, airport and terminal operators, air taxi operators, ground handling and catering organizations, authorized air cargo agencies and general aviation operators (SHGM, 2014).

Another of aviation security practices in Turkey are constricted area. Access to restricted areas at airports is only allowed by personnel authorized on the entry card (SHGM, 2019). Since the airport border gate is accepted, the customs areas where passengers can pass by passports are also within the restricted area. In addition, the airport apron area designated for the parking of aircraft, fuel supply, passenger, cargo, cargo, postage, unloading and overhaul and maintenance of the aircraft is within restricted areas. These areas are considered critical points for safety and security. 


\section{Risk society}

The main purpose of the institutions of the state is to protect the freedom and legal values of individuals with various regulations and to ensure social peace. In order to ensure social peace and trust, it is imperative that the values of people, such as their integrity and property and property, are preserved (Ekinci, 2004).

Beck argues that the risk society is the result of modernization. Risk society is defined as a process that must be experienced and cannot escape. Beck describes seven distinct characteristics of risks in risk society theory as follows (Koçak \& Memiş, 2017):

- Risks are unpredictable. It is difficult to take precautions against unpredictable and unpredictable risks. The events that took place on July $15^{\text {th }}$ at Atatürk Airport are unforeseen.

- The uncertainty of unknown risks revealed the concept of non-insurance. Atomic hazards, nuclear accidents, are not covered by insurance because they do not fall within the definition of previous accidents. The violations that occur due to the violations of the restricted area due to the July 15 incidents are not covered by insurance.

- Risks cross the boundaries of all classes and countries and affect both the rich and the poor. Risks go back to those who make them and gain from them, just like a um boomerang. States are damaging nature in the name of their material interests. This situation causes global climate change. Natural disasters such as hurricanes, storms and floods caused by global climate change cause the damage caused by states to return to nature for material gain. The September 11, 2001 twin-tower attacks, the breaking point in the security of aviation, took place in the United States, where air transport began and developed.

- Risks have arisen in a particular geography, but they are universal and spread all over the world. The events in aviation affect other regions outside of the country in terms of economic, cultural, sociological and psychological aspects.

- Risks in the risk society increase the dependency on experts. However, according to Beck, there is no expert on risks. With the occurrence of specialization, the risks are easily legitimized. At the same time, risks turn into a more dangerous structure through legitimation. The measures taken in the field of aviation security have led to a change in the methods of the terrorists who will take action.

- Today's extinct forests, toxic accidents, contaminated groundwater and seas are visible side effects of risks. Radiation, toxic wastes, nuclear activities are the unseen side effects that Beck calls the "shadow kingdom".

- Risks in our age include more dangers for the future. Beck thinks that the risks in the previous ages are due to chance. Therefore, there are differences between the concept of risk in traditional societies and the concept of risk in the process of modernization and industrialization. 


\section{Ataturk Airport During the Failed Coup Attempt of July $15^{\text {th }}$}

On July $15^{\text {th }}$, at 22:00 hours, gunshots were heard at the General Staff, and a helicopter opened fire on those outside. Bosphorus and Fatih Sultan Mehmet bridges in Istanbul were closed by a group of soldiers (Yllmaz, 2016). The prime minister of the time, Binali Yildirim, stated that there was an attempted coup by connecting to a television channel at 23:05. President Recep Tayyip Erdoğan passed from Marmaris to Dalaman Airport at 00:11 by helicopter and then took off to Atatürk Airport with his plane in the presidential fleet. President Recep Tayyip Erdoğan was in the air at 00:13, the invading soldiers who occupied TRT, had read a pirate coup declaration. At 00:26, President Erdoğan was broadcasted live on CNN Türk, reacting to the military takeoff and invited people to provincial squares and airports. (Cumurbaşkanlığ Sekreterliği, 2016). Erdogan "Take to the streets" the people that made the call, Turkey has gone around the square and airports (Çelikkan, 2017).

All airports have been closed to air traffic by coup soldiers. Istanbul Ataturk Airport was tried to be controlled by 58 coup officers with 4 tanks, 4 armored vehicles, 4 trucks and 4 military jeeps. (Cumurbaşkanlığı Genel Sekreterliği, 2016). TC-ATA (aircraft registration), which will take Erdoğan to Istanbul, used the code "THY 8456" which issued to passenger aircraft, in order to surprise the coup troops. Erdogan took off from Dalaman at 01.43 to go to Ataturk Airport by TC-ATA (Çelikkan, 2017) and the aircraft landed at Atatürk Airport at 3:20 (Cumurbaşkanlığı Genel Sekreterliği, 2016).

According to the information compiled by Anadolu News Agency reporters, the coup attempt of FETO / PDY, which started at 22:00 on Friday, July 15, was eliminated at 20:02 on Saturday, July 16.

The public who went to Atatürk Airport was one of the breaking points for the coup attempt to fail (Çelikkan, 2017). It is estimated that approximately one hundred thousand people came to Atatürk airport upon the call of President Recep Tayyip Erdoğan. On the night of the event, the President referred and directed the state from Atatürk Airport.

\section{Methodology}

The aim of the research is to analyze the flight safety and airport security in the restricted areas of Atatürk Airport during the July $15^{\text {th }}$ military coup attempt. In the first part of the research, the concept of risk and airport security are explained. In the application section of the research, the visual data explained in the press were analyzed and the case study was explained.

This study was conducted on the images that were only collected into the press due to time and cost limits at Istanbul Atatürk Airport and secondary sources were analyzed.

\section{Results and Analysis}

On July $15^{\text {th }}$, the Turkish Armed Forces launched a coup attempt by a group of officers belonging to the FETO / PDY. During the coup attempt, armed interventions were made to the airport security forces, airport personnel and passengers at Atatürk Airport (Cumurbaşkanlığ Genel Sekreterliği, 2016). The Security Plan, which should be implemented in case of 
emergencies prepared under the Civil Aviation Legislation, could not be fully implemented. Therefore, weaknesses occurred in the security management and organizations of aviation enterprises.
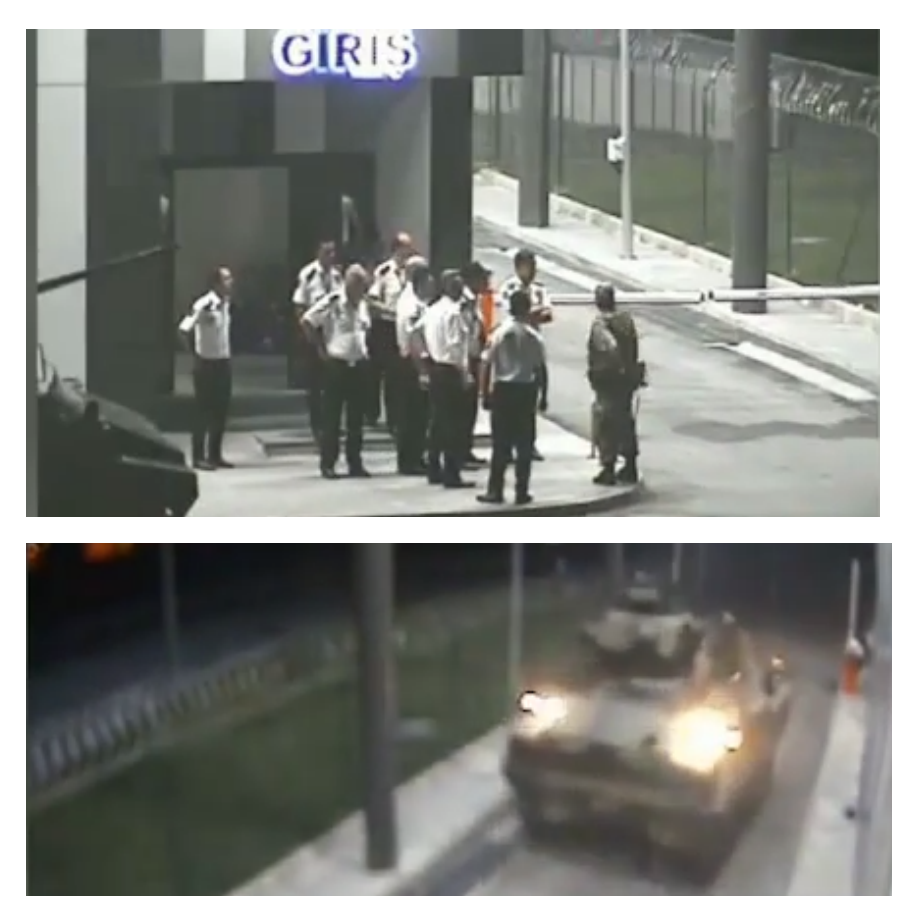

Source: (Anadolu Haber Ajans1, 2016)

Figure 1. Unauthorized Entrance from Ataturk Airport A Gate

Figure 1 shows the unauthorized entry into Atatürk Airport from "Entrance A" by the soldiers FETO / PDY with 1 truck and 3 armored vehicles 07/16/2016 at am 00:55-01:00 (Anadolu Haber Ajans1, 2016). FETO / PDY soldiers was moved in the air side without the permission of the authorities (Directorate of Civil Administration and Directorate of DHMİ of Atatürk Airport). Even though they were not authorized, the trucks and others armored vehicles were driven in the airport movement areas by FETO / PYD soldiers as shown in the pictures (DHMİ, 2019).

Figure 2 shows the parking violations of apron $07 / 16 / 2016$ at $00: 57$, unauthorized identification control, and also driven of truck and 3 armored vehicles violations of apron on 01.07.2016 at 01:02 (Anadolu Haber Ajans1, 2016). "Card Usage / Security Instruction” of National Civil Aviation Security Program was ignored. The crimes, as traveling around the air side without licensed Apron plate, driving in airport movement areas without driving license, faulty parking, disturbance of public order and peace, were endanger to airport safety by FETO / PDY soldiers (DHMI, 2019). The vehicles were parked at the airport apron in order to obstruct the refueling and fire trucks. In addition, it is seen that vehicles contrary to the rules were used in aprons and service roads. 

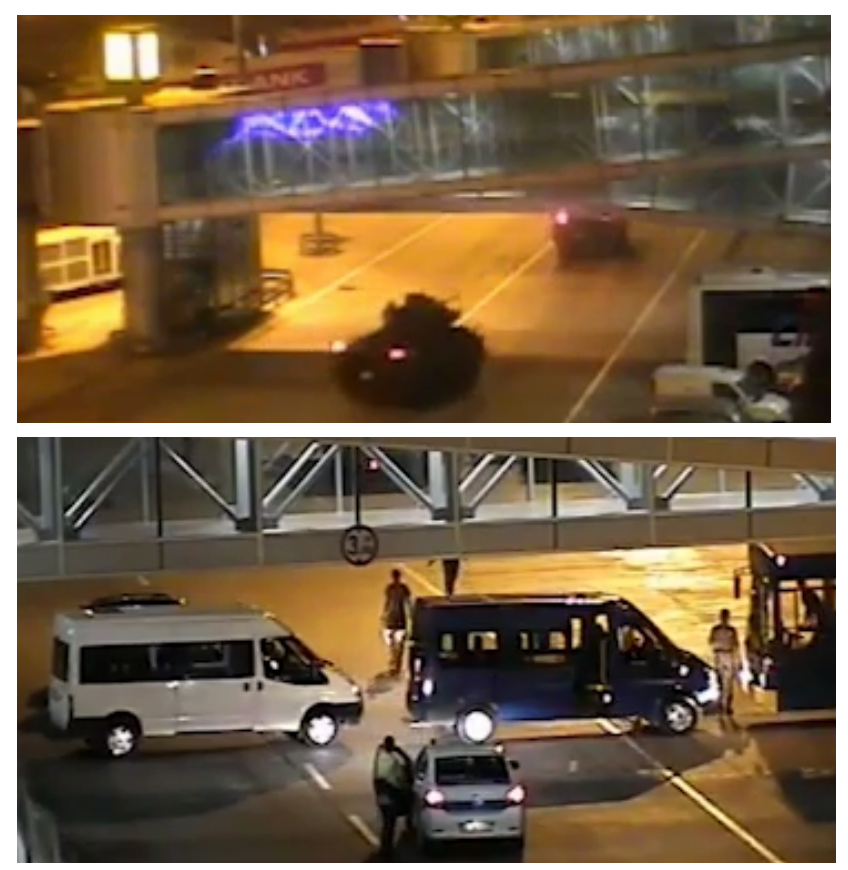

Source: (Anadolu Haber Ajansı, 2016)

Figure 2. Atatürk Airport Apron Traffic Violations and Parking in Prohibited Areas
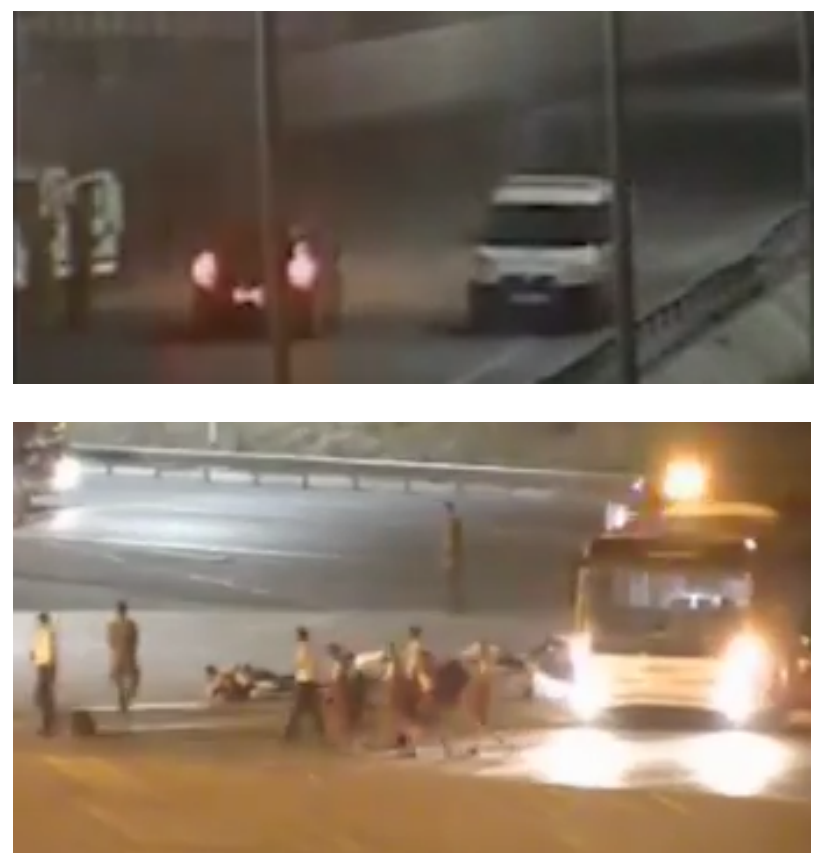

Source: (Anadolu Haber Ajans1, 2016)

Figure 3. Behavior for Providing Security at Border Gates

Figure 3 shows images of FETO / PDY Soldiers usurping the vehicle they stopped in the apron $(07 / 16 / 2016$ at 01:04) and stopping the bus carrying passengers and laying the passengers on the ground (07/16/2016 at 01:03) (Anadolu Haber Ajans1, 2016). From the images, it is understood that flight and ground safety at the airport and airport layout were disrupted and 
the vehicles of the operators carrying out aviation activities at the airport were seized. The entry / exit of the aircraft to the parking spaces was made without the relevant ground handling personnel. It is a crime to use vehicles that are not owned or accounted for in Movement Areas.

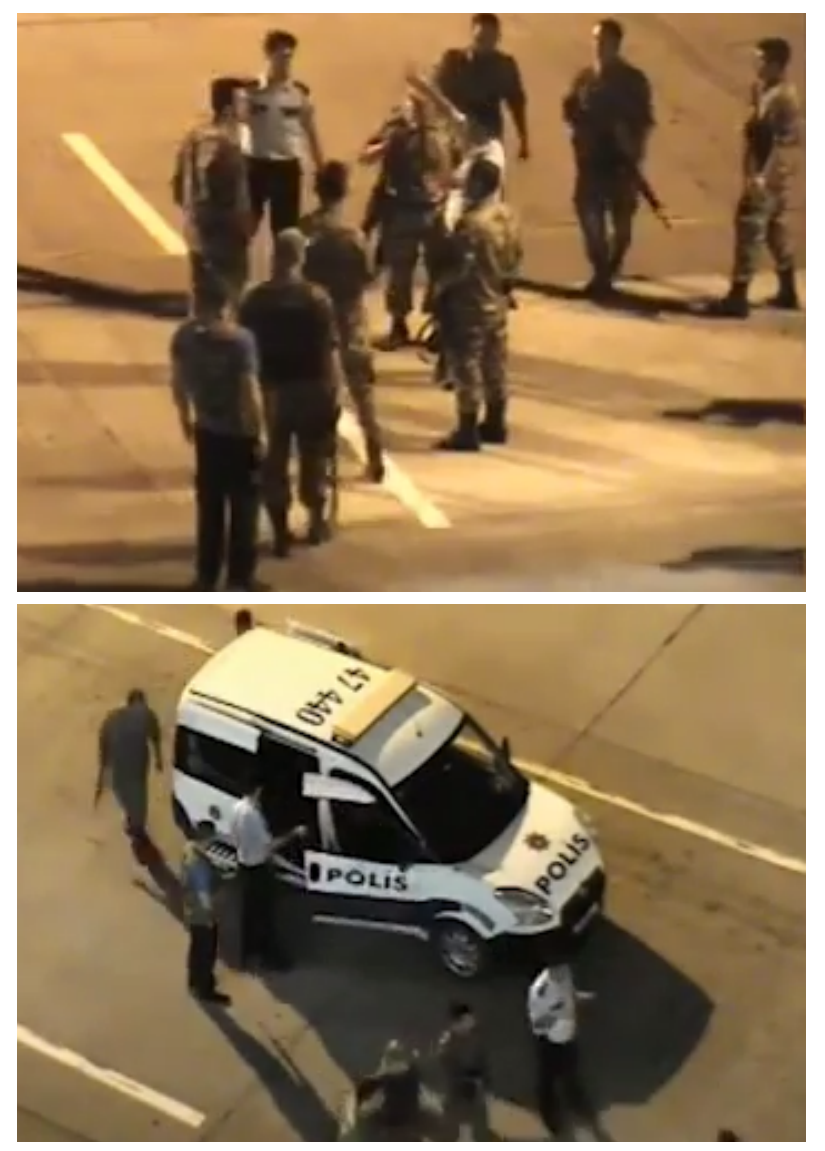

Source: (Anadolu Haber Ajans1, 2016)

Figure 4. Behavior for Uncontrolled Security at Border Gates

Figure 4 shows the images of the FETO / PDY soldiers in the apron capturing the police on 07/16/2016 at 01:35. (Anadolu Haber Ajans1, 2016).

Figure 5 shows the FETO / PDY Soldier's Apron image (07/16/2016 at 00:59) that they were in the air side and without permission from the airport authorities with their guns (Anadolu Haber Ajans1, 2016). They committed a crime by not using the pedestrian crossing that was established for the passage from terminals to aircraft parking spaces. 

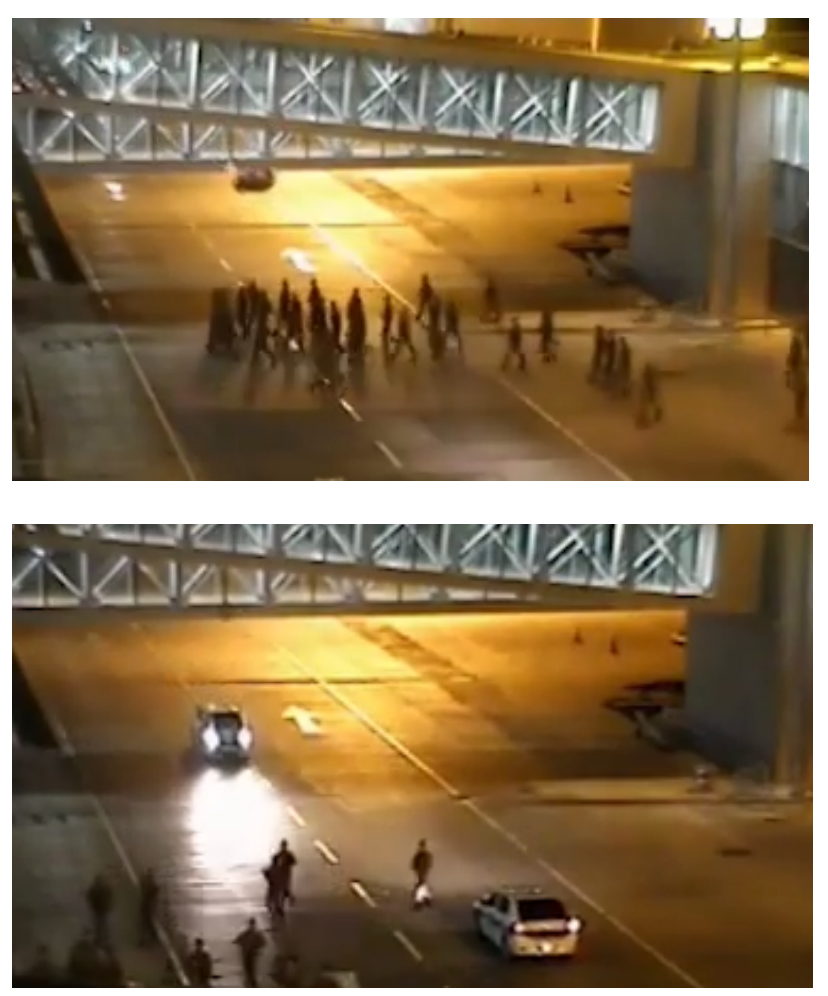

Source: (Anadolu Haber Ajans1, 2016)

Figure 5. Uncontrolled Passing Through Apron Vehicle Road and Endangering Apron Safety
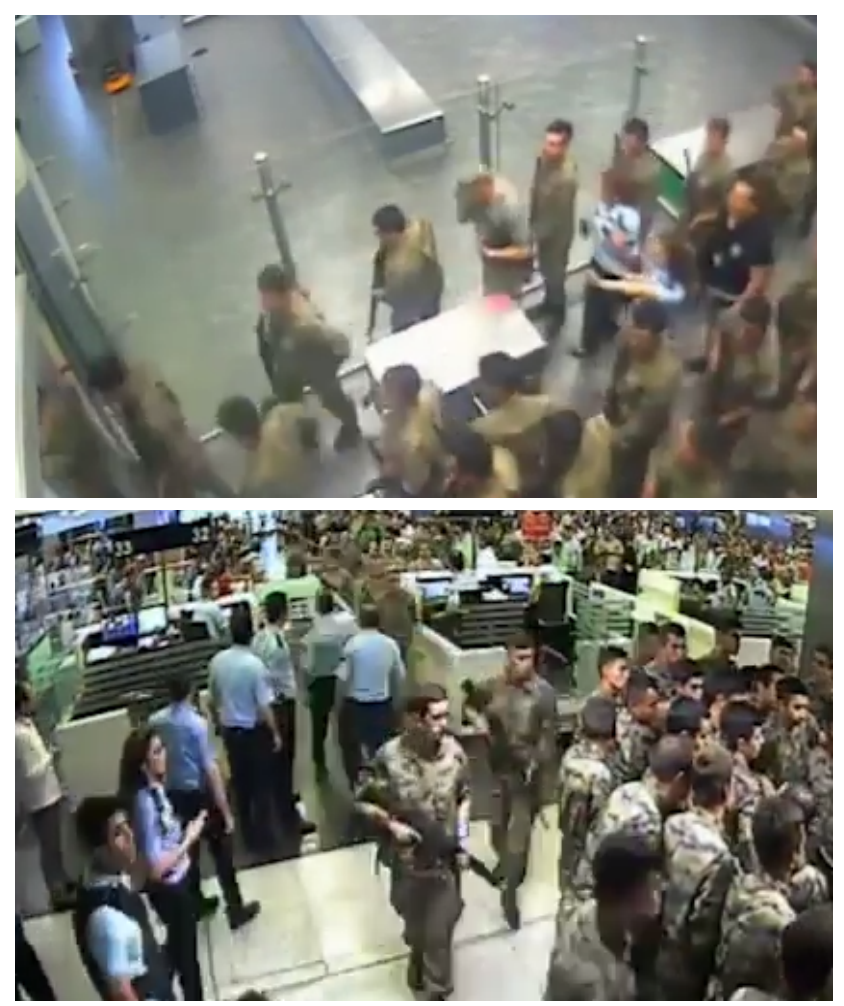

Source: (Anadolu Haber Ajansi, 2016)

Figure 6. Unauthorized Access to the Customs Area 
Airport personnel are prohibited from entering areas that are not allowed onto their apron card, even if they have an entry card. Figure 6 shows the exit of FETO / PDY soldiers (01:19 am) from the international terminal building with their guns and the intervention to the Passport Control Point (01:36 am). (Anadolu Haber Ajansı, 2016).
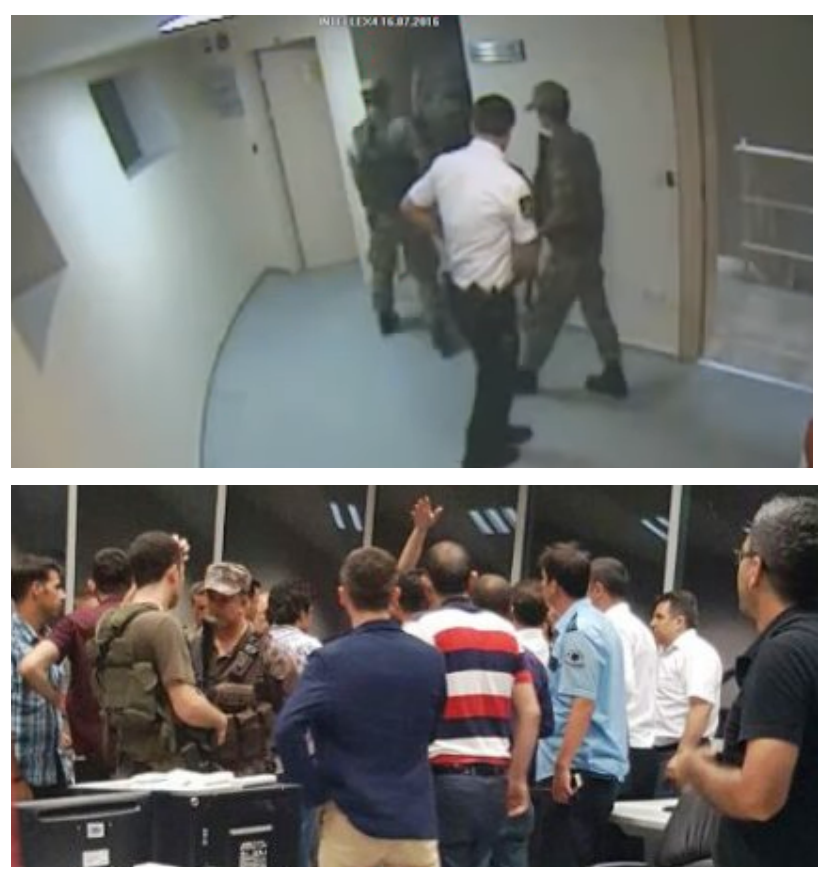

Source: (Anadolu Haber Ajans1, 2016), (Kali, 2016)

Figure 8. Unauthorized Access to the Restricted Area

Figure 8 shows the unauthorized entry into the Air Traffic Control Tower at 00:59 on 07/16/2016 (Anadolu Haber Ajans1, 2016), and nullification to air traffic controller by FETO / PDY soldiers. 

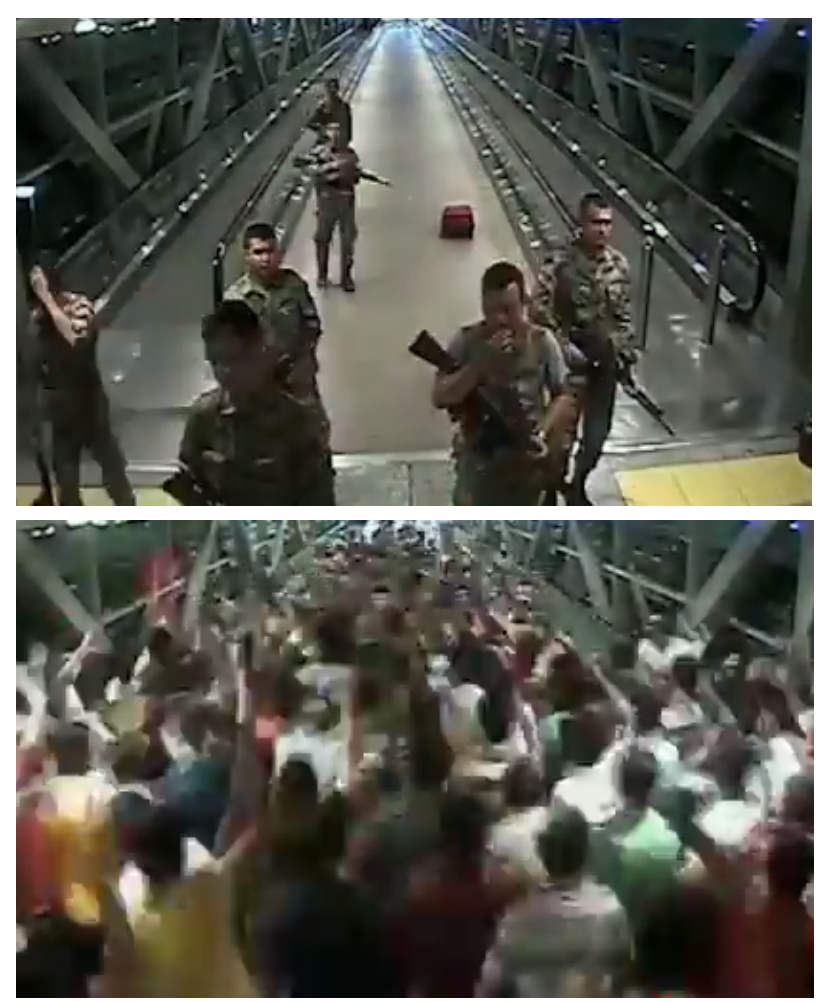

Source: (Anadolu Haber Ajansi, 2016)

Figure 9. Unauthorized Access to Restricted Area

Figure 9 shows the footage of the FETO / PDY Soldier at the international terminal (01:26 am) and the public intervention.
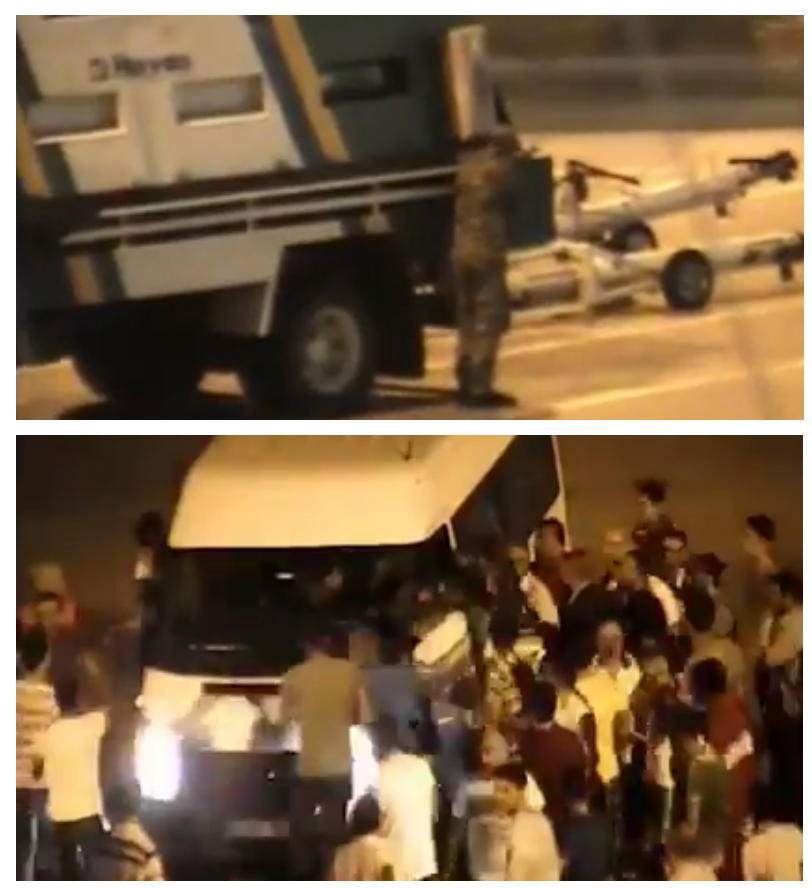

Source: (Anadolu Haber Ajansı, 2016)

Figure 10. Pedestrians that Prevent Maneuvers of Apron Vehicle

In Figure 10, FETO / PDY armed soldiers in the apron position and intervention of public are given (07/16/2016 at 01:48). "Aerodrome Safety Management System" rules were violated. 
Unauthorized entrance to runways and taxiways have compromised aviation safety and security.

When the images are analyzed, it is understood that the international civil aviation regulations such as Annex 14, Annex 19 and Annex 17 of International Civil Aviation Organization were violated in the July $15^{\text {th }}$ by coup attempt. The relevant sections of SHT-17 and SHY 22 issued by the General Directorate of Civil Aviation which is the national civil aviation authority had been violated by coup soldiers. In addition, Card Use \& Security Instruction of the National Civil Aviation Security Program had been ignored. FETO / PDY acted without the permission and knowledge of the competent authorities on the air side (Civil Administration and Atatürk Airport DHMI). Table 1 was prepared for the detected violation.

Table 1. National and Administrative Legislation on Aviation Violated by FETO / PDY on July $15^{\text {th }}$

\begin{tabular}{ll}
\hline TYPE & NAME OF THE VIOLATION OF THE LEGISLATION \\
\hline & Law No. 657 Civil Servants Law \\
& Law No. 5188 on Private Security Services \\
& Decree Law on the Organization and Duties of the Ministry of Transport and \\
& Infrastructure \\
& Law No. 5431 Law on Organization and Duties of General Directorate of Civil \\
& Aviation \\
& Law No. 5793 Law Amending Some Laws and Decree Laws
\end{tabular}

\begin{tabular}{ll}
\hline & $97 / 9707$ Numbered Implementing Regulation on the Security of Civil \\
& Airports, Ports and Border Gates, and the Execution of Duties and Services
\end{tabular}

DHMI Airports Operation Services Directive

DHMI Airports Driving Directive in Movement Area

DHMİ Airports Passenger Bridges Operation Directive

DHMI Disaster and Emergency Response Center Directive
AFAD Management Duty Officer Special Instruction
DHMİ Operational Safety Management System Directive
DHMI Apron Plate Directive
Security Investigation and Archive Research Directive
Quality Management System and Standardization in SHT-CNS / ATM
Dervices
Department of Business Regulation
Department of Occupational Health and Safety Regulation




\section{Conclusion and Suggestions}

Fetullah Terrorist Organization / Parallel State Structure coup attempt on July $15^{\text {th }}$ was taken under control by government. Attempt to occupy dozens of security and safety regulation were evaded in the Ataturk Airport about the aviation. The airport operator couldn't take the precaution to ensure that airport services were carried out at national and international standards on occupy attempt. Occupy soldiers and resisting people confronted in the Atatürk Airport restricted area.

Commitment, as a form of concept and understanding, is the emotional expression of social instinct, even where there is a sense of society. Commitment, one of the most powerful emotions felt by individuals, refers to commitment to a person, a thought, an institution, and the obligation they have to fulfill. Turkish citizens resisted to FETO/PDY occupy with this commitment and loyalty feeling.

The coup soldiers violated the restricted area and tried to take control of the apron area and the other restricted area within the terminal. The armed forces intervened in the airport security forces, airport personnel and passengers. Also, millions of dollars' worth of airplanes in the apron, hazardous material class as refueling facilities, duty-free areas within the customs area remained vulnerable.

Upon the call of President Recep Tayyip Erdoğan to the airport, approximately one hundred thousand people entered security restricted areas and intervened in the coup soldiers. The people entering Atatürk Airport did not harm the aircraft, equipment and dangerous fuel facilities in the apron area during the $15^{\text {th }}$ of July incidents. It may a future research about will be made by sociologists and psychologists about the social risk elements such as looting which act was not realized in duty-free shopping areas, apron areas and other facilities in Atatürk Airport.

\section{References}

Anadolu Haber Ajansı. (2016). Retrieved September 05, 2019, from https://www.youtube.com/watch?v= q43tHdDsvLQ\&t=546s;

Anadolu Haber Ajansi. (2016). Retrieved September 05, from https://www.youtube.com/watch?v=Wdg8Oq wHha c\&t=139s;

Anadolu Haber Ajansi. (2016). Retrieved September 05, from https://www.youtube.com/watch?v=I8WFYK qetDg\&t=54s;

Anadolu Haber Ajansi. (2016). Retrieved September 05, from https://www.youtube.com/watch?v=kna_ch YHQuw

Ateş, A. S., Yılmaz, H., Sayın, A., \& Kardeş, Y. (2016). Interrelation Between Organizational and Professional Commitment Application on Airport Security Officer in Turkey. Balkan ve Yakın Doğu Sosyal Bilimler Dergisi, 2(4) 49-58.

Cumurbaşkanlığı Genel Sekreterliği. (2016). 15 Temmuz Darbe Girişimi ve Milletin Zaferi. Ankara: Cumhurbaşkanlığı Kurumsal İletişim Başkanlığı. 
Çelikkan, E. (2017, June 14). Erdoğan'ın darbe gecesi kritik anları. Hürriyet. Retrieved November 25, 2019, from http://www.hurriyet.com.tr/15-temmuz-yildonumu/erdoganindarbe-gecesi-kritik-anlari-40519101

DHMİ. (2019). Devlet Hava Meydanları Issletmesi Genel Müdürlüğü. Retrieved November 15, 2019, from Kanun ve Yönetmelikler: https://www. dhmi.gov.tr/sayfalar/kanunveyonetmelikler.aspx

Ekinci, E. E. (2004). Yağma Suçu. (Yayımlanmamış Yüksek Lisans Tezi) Dokuzeylül Üniversitesi Sosyal Bilimler Enstitüsü Kamu Hukuku Anabilim Dalı, İzmir.

HYSK. (2018, Ağustos 24). FETÖ/PDY Silahlı Terör Örgütü Soruşturma Süreci ve İntikal. Karar No: 2016/426, Tutanak No:14.

ICAO. (2017). Annual Report 2017 The World of Air Transport in 2017. Montreal: ICAO. Retrieved from Montreal: ICAO. Retrieved from: 12 February 2019. https://www.icao.int/annual-report-2017/Pages/the-world-of-air-transport-in-2017.aspx

Kali, M. (2016, June 24). Atatürk Havalimanı'nda kuleye baskın anı kamerada. Aeroport İst. Retrieved from: 12 February https://www.aeroportist. com/ataturk-havalimaninda-kuleyebaskin-ani-kamerada.html

Koçak, H., \& Memiş, K. (2017). Ulrich Beck'in Risk Toplum Teorisi Bağlamında Güvenlik ve Özgürlük İkilemi. Afyon Kocatepe Üniversitesi Sosyal Bilimler Dergisi, 19(2), 251-265. doi:02397680061931

Sandıklı, A. K. (2011). Teoriler Işı̆̆ında Güvenlik, Savaş, Barışve Çatışma Çözümleri. İstanbul: Bilge Adamlar Stratejik Araştırmalar Merkezi.

Scherer, C. (2019). Global Market Forecast Cities, Airports \& Aircraft 2019-2038. Airbus. Retrieved from : 12 Agust 2019 https://www.airbus.com /content/dam/corporatetopics/strategy/global-mark et-forecast/GMF-2019-2038-Airbus-Commercial-Aircraftbook.pdf

SHGM. (2014). Havacılık İşletmeleri Güvenlik Yönetimi ve Organizasyonu Talimatı”. Ankara: SHGM.

SHGM. (2019). Sivil Hava Meydanları, Limanlar ve Sınır Kapılarında Güvenliğin Sağlanması, Görev ve Hizmetlerin Yürütülmesi Hakkında Yönetmelik. Ankara: 14/2/2019 tarihli ve 30686 sayılı Resmî Gazete.

SHGM. (2019). Sivil Hava Meydanları, Limanlar ve Sınır Kapılarında Güvenliğin Sağlanması, Görev ve Hizmetlerin Yürütülmesi Hakkında Yönetmelik. Ankara: 14/2/2019 tarihli ve 30686 sayılı Resmî Gazete.

Sweet, K. M. (2008). Aviation and Airport Security: Terrorism and Safety Concern. London: CRS.

Yılmaz, S. (2016, Ağustos). Beştepe Millet Camisinde Milletin Destanı: Vatan İçin, Millet İçin Yaşasın Türkiye. Kardeş Kalemler Aylı Avrasya Edebiyat Dergisi, 116, 28-31. 